\title{
ПІДГОТОВКА ФАХІВЦІВ У ВИЩИХ НАВЧАЛЬНИХ ЗАКЛАДАХ УКРАЇНИ В СУЧАСНИХ УМОВАХ НА ОСНОВІ КОМПЕТЕНТНІСНОГО ПІДХОДУ
}

Г. Я. Загричук, В. П. Марценюк, І. Р. Мисула

ДВНЗ “Тернопільський держсавний медичний університет імені І. Я. Горбачевського МОЗ Украӥни”

\section{TRAINING OF SPECIALISTS IN HIGHER EDUCATIONAL INSTITUTIONS OF UKRAINE IN MODERN CONDITIONS BASED ON COMPETENCY APPROACH}

\author{
H. Ya. Zahrychuk, V. P. Martsenyuk, I. R. Mysula \\ SHEI "Ternopil State Medical University by I. Ya. Horbachevsky of MPH of Ukraine"
}

\begin{abstract}
У статті розглянуто модель підготовки висококваліфікованих фахівців у сучасних умовах на основі компетентнісного підходу.
\end{abstract}

The article describes the model of training of highly qualified specialists in modern conditions based on competency approach.

Вступ. Питання якості вищої освіти та підготовка висококваліфікованих фахівців у вищих навчальних закладах (ВНЗ) України є на сьогоднішньому етапі досить актуальним. Низька репутація випускників окремих галузей серед роботодавців, недостатній рівень практичної підготовки і низький рівень працевлаштування випускників за фахом свідчать про певну недосконалість системи вищої освіти в Україні. Приєднання України до Болонського процесу [1] 3 метою створення єдиного Європейського простору вищої освіти (СПВО) зобов'язало провести ряд реформ у сфері вищої освіти:

1) розробити Національну рамку кваліфікацій (НРК);

2) реалізувати реформи навчальних програм ВНЗ на основі результатів навчання, компетентнісного підходу з урахуванням реальних потреб ринку праці;

3) забезпечити мобільність студентів та викладачів;

4) розширити автономію навчальних закладів.

Метою публікації є презентація моделі підготовки фахівців у вищих навчальних закладах України в сучасних умовах на основі компетентнісного підходу.

Основна частина. Відповідно до діяльнісно-компетентнісного підходу професійна компетентність фахівця визначається рівнем власної освіти, досвідом, індивідуальними здібностями, постійним прагненням до самоосвіти, творчим ставленням до своєї справи, готовністю та спроможністю до виконання профе- сійної діяльності [2]. Прийнята Постанова Кабінету Міністрів України за № 1341 від 23.11.2011 р. "Про затвердження Національної рамки кваліфікацій” [3] i спільний наказ МОНмолодьспорту та Мінсоцполітики за № 488/225 від 20.04.2012 р. “Про затвердження Плану заходів щодо впровадження Національної рамки кваліфікацій" [4] потребують розробки стандартів освіти (освітньо-кваліфікаційної характеристики $(\mathrm{OKX)} \mathrm{й} \mathrm{освітньо-професійної} \mathrm{програми}(\mathrm{OПП))} \mathrm{та}$ стандартів компетентностей для освітніх та професійних кваліфікацій на основі системи компетентностей НРК. На першому етапі, з метою зближення освітніх та професійних кваліфікацій з НРК, а також відповідності підготовлених фахівців реальним потребам ринку праці залучення замовників освітніх послуг - роботодавців - до процедури створення нових ОКХ фахівця відповідної спеціальності є необхідною реальністю та правом роботодавців. Зокрема, відповідно до статті 26 Права організацій роботодавців, їх об'єднань у сфері вищої, професійно-технічної освіти, навчання на виробництві Закону України “Про організації роботодавців, їх об'єднання, права i гарантіїї діяльності” організації роботодавців, їх об'єднання в установленому порядку беруть участь у розробленні державного стандарту професійно-технічної освіти, державного стандарту вищої освіти; розробленні та погодженні державних стандартів 3 конкретних професій, галузевих стандартів вищої

(ㄱ Г. Я. Загричук, В. П. Марценюк, I. Р. Мисула 
освіти, стандартів вищої освіти вищих навчальних закладів, кваліфікаційних характеристик, професійних стандартів [5]. В основі новостворених державних стандартів вищої освіти мають бути закладені не тільки спеціальні (фахові) компетентності, але й загальні. На сьогодні з позиції європейських випускників та роботодавців до найбільш важливих загальних компетентностей належать такі: 1) інструментальні (когнітивні, методологічні, технологічні та лінгвістичні здатності) - здатність до аналізу та синтезу, розв'язання проблем, навики управління інформацією, здатність до організації та планування; 2) міжособистісні (соціальна взаємодія та співпраця) - робота в групі; 3) системні (поєднання розуміння, сприйнятливості та знань) - здатність до навчання, здатність застосовувати знання на практиці, здатність до адаптації в нових умовах, турбота про якість, здатність працювати автономно тощо.

Наступним етапом є створення на основі прийнятої ОКХ навчальним закладом ОПП, в якій мають бути відображені результати навчання - сукупність узагальнених завдань, для виконання яких студент повинен залучати конкретні “'знання, уміння й компе- тенції”. Результати навчання повинні бути сформульовані до початку навчальної діяльності. Необхідно зазначити, що в структурі ОПП співвідношення між циклами гуманітарної та соціально-економічної, природничо-наукової та професійно-орієнтованої підготовки повинні мати, з одного боку, певні зафіксовані межі, щоб навчальні заклади не зловживали в перерозподілі годин. 3 іншого боку, вибір переліку навчальних дисциплін ВНЗ та самостійного вибору студентів, особливо якщо це стосується гуманітарної та соціальноекономічної, природничо-наукової підготовки, має визначатися в першу чергу можливістю досягнути очікуваних результатів навчання та компетентностей, а не регламентуватися відповідними наказами чи директивними документами. Цей же принцип повинен бути витриманий і при визначенні співвідношення між теоретичною і практичною частинами циклу професійно-орієнтованої підготовки.

Наступним кроком в реалізації підготовки висококваліфікованих фахівців на основі компетентнісного підходу $є$ створення нових типових навчальних програм 3 дисципліни на основі зіставлення результатів навчання (PH) та компетентностей за такою матрицею [6]:

\begin{tabular}{|c|c|c|c|c|c|c|}
\hline \multirow{2}{*}{$\begin{array}{c}\text { Результати навчальної програми } \\
\text { напряму/спеціальності } \\
\text { Випускник може: }\end{array}$} & \multicolumn{5}{|c|}{ Модулі програми } & \multirow[b]{2}{*}{$\begin{array}{c}\text { Відношення до } \\
\text { РН напряму }\end{array}$} \\
\hline & MK_1 & MK_2 & MK_3 & $\ldots$ & MK_m & \\
\hline Ідентифікувати і визначати ... & & + & & & ++ & H_3 $31, H_{-} 3_{\mathrm{O} 3}$ \\
\hline Формулювати ... & + & & & & & $\mathrm{H} \_33_{\mathrm{O} 2}, \mathrm{H} \_33_{\mathrm{O} 7}$ \\
\hline \multicolumn{7}{|l|}{$\ldots$} \\
\hline Розв'язувати ... & ++ & & +++ & & + & $\begin{array}{c}\mathrm{H}_{-} \mathrm{y}_{\mathrm{O} 1}, \mathrm{H}_{-} \mathrm{y}_{\mathrm{O} 2}, \\
\mathrm{H} \_\mathrm{y}_{\mathrm{O} 9}\end{array}$ \\
\hline Проектувати ... & & ++ & & & & $\mathrm{H} \_\mathrm{y}_{\mathrm{O} 3}, \mathrm{H} \_\mathrm{y}_{\mathrm{O} 6}$ \\
\hline Оцінювати ... & & & & & +++ & $\mathrm{H} \_\mathrm{y}_{\mathrm{O} 4}, \mathrm{H} \_\mathrm{y}_{\mathrm{O} 5}$ \\
\hline \multicolumn{7}{|l|}{$\ldots$} \\
\hline Працювати в групі ... & & + & & & & $\mathrm{H}_{-} \mathrm{C}_{\mathrm{O} 1}, \mathrm{H} \_\mathrm{C}_{\mathrm{O} 4}$ \\
\hline Ефективно комунікувати із ... & & & & & ++ & $\mathrm{H}_{-} \mathrm{C}_{\mathrm{O} 2}$ \\
\hline
\end{tabular}

При аналізі матриці результатів навчання потрібно враховувати:

- матриця містить пустий рядок: запланований РН не засвоюється в процесі навчання за даною програмою (не відображений в жодному модулі);

- слабо заповнений рядок: засвоєння запланованого РН є під загрозою (залежить лише від одногодвох модулів);

- занадто заповнений рядок: запланований РН домінує в програмі, можливо, коштом інших;

- слабо заповнений стовпець: даний модуль не вносить істотного вкладу в програму.

Такого типу аналіз дозволяє виявити слабкі місця в навчальній програмі, внести необхідні зміни в склад і зміст модулів. Аналіз необхідно повторювати після кожної ітерації оновлення програми [6].

Тому при побудові навчальних програм на основі компетентнісного підходу необхідно уникати як занадто великої, так і занадто малої деталізації результатів навчання. Зокрема, Європейська кредитна трансферно-накопичувальна система (ЄКТС) навчання рекомендує встановлювати не більше 6-8 результатів навчання для кожного модуля, оскільки для отримання кваліфікації студент повинен засвоїти всі результати навчання.

Надалі з метою забезпечення успішного досягнення запланованих результатів навчання викладачами ВНЗ має бути створено відповідне навчально-мето- 


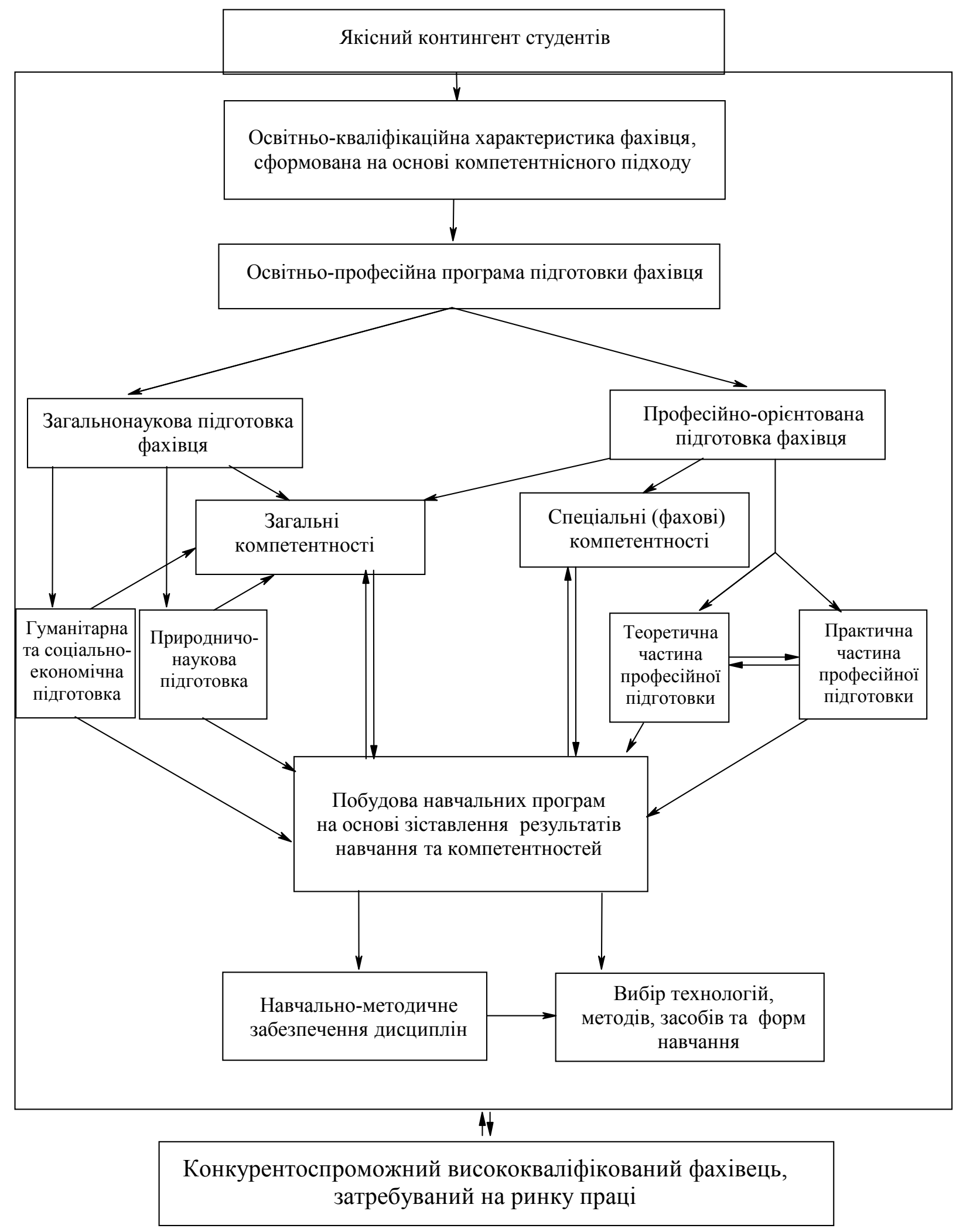

Cхема 1. Модель підготовки фахівців на основі компетентнісного підходу.

дичне забезпечення з дисципліни, що включає: конспекти лекцій, презентації лекцій, зошити з практичних (лабораторних) робіт, посібники, матеріали підготовки до практичних занять та лекцій [7].
Не менш важливою складовою в підготовці фахівців $€$ вибір навчальним закладом та його викладачами технології, методів, засобів та форм навчання: впровадження інформаційно-комунікаційних, інно- 
ваційних технологій, ідей студентоцентризму - реалізації індивідуального темпу засвоєння навчального матеріалу тощо.

При побудові та реалізації навчальних програм важливим компонентом $€$ забезпечення міжпредметних зв'язків, реалізація яких може бути забезпечена впровадженням сучасних методик навчання. Зокрема, в ДВНЗ “Тернопільський державний медичний університет імені I. Я. Горбачевського МОЗ України" впродовж останніх років успішно реалізується практично-орієнтоване навчання (Z-система навчання) [8, 9], в результаті якого студенти ще при вивченні фундаментальних дисциплін поряд із вивченням теорії розглядають клінічні дані, дають їм пояснення тощо. Так, при вивченні анатомії студенти поряд із препаруванням фізичних тіл на кожному занятті вивчають рентгенограми, комп'ютерні та магніторезонансні томограми; при вивченні біохімії студенти одержують індивідуальне завдання, після виконання якого дають інтерпретацію отриманому біохімічному показнику; на заняттях з клініко-лабораторної діагностики студенти працюють безпосередньо 3 клінічним матеріалом, з використанням сучасних біохімічних аналізаторів, знайомляться з особливостями проведення імунологічних досліджень, полімеразно-ланцюгової реакції, аналізують показники, отримані при різних видах патологічних станів; при вивченні нормальної фізіології студенти не тільки знайомляться з основними функціональними методиками дослідження організму, їх результатами, але й з методикою виконання та запису результатів, працюють 3 комп’ютер-

\section{Література}

1. Комюніке Конференції Міністрів країн Свропи, відповідальних за сферу вищої освіти “'Загальноєвропейський простір вищої освіти - досягнення цілей”, м. Берген, 19-20 травня $2005 \mathrm{p}$.

2. Шиян Л. К. Работодателя сегодня интересует профессиональная компетентность специалиста, а не оценки за знания, выставленные в дипломе / Л. К. Шиян // Ціннісні пріоритети освіти у XXI столітті : матеріали Міжнародної науково-практичної конференції. Ч. 1. - Луганськ, 2003. C. 47-51.

3. Про затвердження Національної рамки кваліфікацій : Постанова Кабінету Міністрів України № 1341 від 23.11.11.

4. Про затвердження Плану заходів щодо впровадження Національної рамки кваліфікацій : наказ МОНмолодьспорту та Мінсоцполітики № 488/225 від 20.04.12.

5. Про організації роботодавців, їх об'єднання, права i гарантії їх діяльності : Закон України від 22.06.12.

6. Рашкевич Ю. Побудова навчальних програм на основі компетентнісного підходу / Ю. Рашкевич // Свро- ним периграфом, аудіотестерами, електронним аномалоскопом, автоматичним рефрактометром, електроофтальмоскопом, електронними спірографами, ацидогастрометрами тощо.

Не менш важливою складовою підготовки висококваліфікованого спеціаліста є формування якісного контингенту студентів. На сучасному етапі це здійснюється на основі проведення зовнішнього незалежного оцінювання (ЗНО) знань випускників, врахування середнього бала атестата, підняття прохідного бала у ВНЗ. Проте більш доцільною, на думку експертів у галузі освіти і на нашу також, є заміна середнього бала атестата на проведення тесту на загальну навчальну компетентність (здатність до навчання) [10].

Таким чином, підсумовуючи викладене, можна запропонувати наступну модель забезпечення підготовки висококваліфікованих фахівців у сучасних умовах на основі компетентнісного підходу (схема 1).

Висновки. Для реалізації запланованої моделі необхідно здійснити ряд заходів:

1) на державному рівні необхідно створити нові стандарти освіти на основі компетентнісного підходу;

2) на рівні ВНЗ на основі затверджених ОКХ розробити відповідно ОПП, навчальні програми з дисциплін та відповідне навчально-методичне забезпечення дисципліни;

3) при створенні нових типових програм з дисципліни в основу побудови змісту програми необхідно покласти результати навчання;

4) при організації навчального процесу у ВНЗ широко використовувати сучасні інноваційні технології навчання.

пейська інтеграція вищої освіти України в контексті Болонського процесу : матеріали Міжнародної науково-практичної конференції, 25-26 жовтня 2012 р., м. Київ. -К., 2012.

7. Загричук Г. Я. Концептуальні підходи щодо покращення якості підготовки фахівців / Г. Я. Загричук, В. П. Марценюк // Медична освіта. - 2012. - № 4. - С. 44-47.

8. Ковальчук Л. Я. Впровадження нової методики навчального процесу в Тернопільському державному медичному університеті імені І. Я. Горбачевського / Л. Я. Ковальчук // Медична освіта. - 2007. - № 2. - С. 16-20.

9. Досвід запровадження практично-орієнтованого навчання для студентів медичного факультету / І. Р. Мисула, А. Г. Шульгай, Г. Я. Загричук [та ін.] // Медична освіта. 2009. - № 1.-С. $14-16$.

10. Про проведення в 2010-2012 рр. експерименту з упровадження тесту загальної навчальної компетентності : наказ Міністерства освіти і науки України від 28.12.09 // Вісник TIMO. -2010. - № 1.-C. 20-24. 